IJLRES - International Journal on Language, Research and Education Studies

ISSN: 2580-6777 (p); 2580-6785 (e)

DOI: $10.30575 / 2017 /$ IJLRES-2018091210

Vol. 2, No. 3, 2018

Page: $420-435$

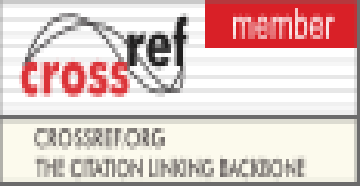

\title{
POLICY IMPLEMENTATION IN IMPROVING TEACHERS' COMPETENCE AT THE MINISTRY OF RELIGION AFFAIRS OF NORTH SUMATRA PROVINCE
}

\author{
Nurhaizan Sembiring \\ Faculty of Islamic Education, The Islamic University of Sumatera Utara \\ nurhaizan@gmail.com
}

\begin{abstract}
This research aims to determine the extent of efforts to increase the competence of Islamic Religious Education teachers in the Ministry of Religion of North Sumatra Province, especially for Islamic Religious Education teachers who teach in public schools. This is qualitative research, researchers conducted interviews directly with stakeholders involved in efforts to improve teacher competency in the North Sumatra provincial ministry of religion offices, they were Head of Office, Head of the section on Islamic religious education, Head of education and training centers and teachers directly involved in every activity to improve competence. The results of this study have found the following; 1) Increasing teacher competence has become a top priority in the section on Islamic religious education through planning activities such as workshops, training, seminars and direct assistance to teachers. Costs in these activities have been budgeted in the DIPA of the Ministry of Religion of North Sumatra Province each year. 2) The Workshop Implementers and various trainings are the Office of Religious Education and Training of the Province of North Sumatra which specifically has the task of conducting training. 3) Participants involved in the training are all PAI Teachers who teach in public schools. The implementation of these activities is periodically arranged according to needs. Thus, increasing the competence of Islamic Education teachers in the Office of the Ministry of Religion of North Sumatra Province has been programmed and carried out according to the needs
\end{abstract}

\section{INTRODUCTION}

Based on Law Number 14 of 2005, the government in the following program issued various rules stated in the Republic of Indonesia National Minister of Education Regulation Number 16 of 2007 concerning academic qualification standards and teacher competencies stating that each teacher must meet the standards of academic qualifications and teacher competency which applies nationally.

In the next regulation, the government explained it through the Director General's Decision on Islamic Education Number 5978 of 2015 concerning the implementation of various activities to improve teacher competency. That on the concept of consideration in order to improve the quality of Islamic Education in junior high schools there needs to be an increase in the activities of Islamic Religious Education teachers. 


\section{Policy Implementation in Improving Teachers' Competence at The Ministry Of \\ Religion Affairs Of North Sumatra Province \\ DOI: 10.30575/2017/IJLRES-2018091210}

Further explained, this activity was implemented in a series of programs with various trainings, workshops and coaching which were followed by a continuing professional program organized by the government in this case the Ministry of Religion of North Sumatra Province.

Article 10 states that the teacher's competencies include pedagogical competence, personality competence, social competence and professional competence. By having these four competencies, it is expected that educators (teachers) can carry out their duties professionally. The competencies that educators must possess are truly ideal, therefore, educators must always study diligently on the sidelines of carrying out their duties.

\section{LITERATURE REVIEW}

\section{Juridical Platform of Teacher Competence}

Teacher competence is listed in Law No. 14 of 2005, that a teacher and lecturer are professional educators with the main task of educating, teaching, guiding, directing, training, evaluating, and evaluating students in early childhood education in formal, basic education and medium. The word competency is also regulated in law. Competence is a set of knowledge, skills, and behaviors that must be owned, internalized, and controlled by the teacher or lecturer in carrying out professional duties.

Professionalism is a special field of work carried out based on the following principles:

a. Have talent, interest and vocation and idealism

b. Have a commitment to improve the quality of education, faith, fear and noble character

c. Have academic qualifications and educational background in accordance with the field of duty.

d. Have the necessary competencies in accordance with the field of duty.

e. Have responsibility for carrying out professional duties.

f. Obtain income determined according to work performance

g. Have the opportunity to develop professionalism continuously with lifelong learning. 


\section{Nurhaizan}

h. Have a guarantee of legal protection in carrying out professional duties and having a professional organization that has the authority to regulate matters relating to teacher professionalism.

\section{The Nature of Teacher Competence}

The term competency has many meanings, broke and stone in Mulyasa suggests Competency as "... descriptive of qualitative nature of teacher behavior appears to be entirely meaningful", meaning that competency is a description of the qualitative nature of the behavior of teachers or education personnel who seem very meaningful. Thus competence is a combination of knowledge, skills, values and attitudes reflected in the habit of thinking and acting. ${ }^{1}$

Some aspects or domains contained in the concept of competence, among others:

a. Knowledge, namely awareness in the cognitive field, namely where a teacher knows the ways to identify learning needs and how to do learning for students according to their needs.

b. Understanding, namely the depth of cognitive and affective owned by individuals, namely where a teacher who will carry out learning must have a good understanding of the characteristics and conditions of students, in order to carry out learning effectively and efficiently.

c. Ability, which is something that is owned by an individual to do a task or work that is charged to him. Namely a teacher in choosing and making simple teaching aids to provide ease of learning to students.

d. Value, which is a standard of behavior that has been believed and psychologically united in a person, namely the standard of teacher behavior in learning (honesty, openness, democratic)

e. Attitude, which is feeling happy / unhappy) or a reaction to an stimulus that comes from outside, namely the reaction to the economic crisis, the feeling of rising wages / salaries

f. Interest is the tendency of someone to do something, namely the interest to learn or do something. ${ }^{2}$

\section{3), p. 62}

${ }^{1}$ H.E. Mulyasa, Uji Kompetensi Dan Penilaian Kinerja Guru (Bandung:Remaja Rosdakarya, ${ }^{2}$ Ibid, p. $63-64$ 


\section{Policy Implementation in Improving Teachers' Competence at The Ministry Of \\ Religion Affairs Of North Sumatra Province \\ DOI: 10.30575/2017/IJLRES-2018091210}

\section{The Competence of Teachers}

\section{Pedagogic Competence}

In the realm of pedagogic competence, teachers carry out various programs with learning design, covering 3 aspects in their activities, namely:

1. 1. Identify needs, which is a gap between what should be and the actual conditions.

2. 2. Identification of competencies, which is something that students want to have, and is the main component that must be formulated in learning. This competency is a combination of knowledge, skills, values and attitudes reflected in the habit of thinking and acting. Then hints that the formation of competencies involves intelligence question (IQ) emotional intelligence (EI), creativity intelligence (CI) which as a whole must be focused on the formation of spiritual intelligence (SI). Thus there is a relationship between the tasks learned by students in schools with the abilities needed by the world of work and living in a community.

\section{Personality Competence}

Personality competence is an ability that must be possessed by every teacher in the form of a stable, stable, mature, wise and authoritative attitude and attitude, becoming a role model for students and noble character. Personal teachers have a huge contribution to the success of education, especially in learning activities. Personality competence has a very important role and function in shaping the personality of the child, in order to prepare and develop human resources (HR) as well as the welfare of society, the progress of the country and the nation in. ${ }^{3}$

\section{Social Competence}

Social competence is the ability of the teacher, as part of the community, to communicate and interact effectively with students, fellow educators, education staff, parents / guardians, students and the surrounding community. The social competence encapsulates various criteria, namely:

1. Communicate verbally, written and gestured.

\footnotetext{
${ }^{3}$ Ibid, p. 117
} 


\section{Nurhaizan}

2. Use communication and information technology functionally

3. Associate effectively with students, fellow educators, education staff, parents / guardians of students and Hang out politely with the surrounding community. 4

\section{METHODOLOGY}

This study uses a qualitative method that seeks to explore various information based on empirical data and facts in the field, and is logical, meaning that it is acceptable to reason. This research is qualitative because it can see problems holistically, complex and dynamic and full of meaning so that it is more capable in obtaining data and problems in the competence of the PAI teachers.

This qualitative approach was chosen, of course, related to the object under study providing empirical data about teacher competencies within the Ministry of Religion in North Sumatra Province. To complement this qualitative approach, educational methods are used that attempt to examine holistically the PAI teacher competency policies in the Ministry of Religion of North Sumatra Province. The researcher also intends to understand the situation and conditions in depth, by finding various findings through observation, interviews and examining various documents for completeness in this study. This type of research has characteristics such as the actual setting, the researcher is the key instrument and the data is descriptive, which emphasizes the process and analysis of the data is inductive and the meaning of each event is essential attention in qualitative research. ${ }^{5}$

\section{FINDINGS AND DISCUSSION}

\section{Program for Implementing PAI Teacher Competency Improvement Policies in the Ministry of Religion, North Sumatra Province.}

Talking about the program, which was planned in the implementation of this policy, was started on the background of various factors that led to the program, referring to the results of interviews with the head of PAKIS who stated that:

"The background of the emergence of the policy of increasing the competence of teachers in the environment of PAI I of the Ministry of Religion of North Sumatra province is that the problematic phenomenon of religious education that emerged

\footnotetext{
${ }^{4}$ E. mulyasa, p. 173

${ }^{5}$ Bogdan, R.C Dan Biklet, S.K, Qualitative Research (Boston: Allyin Dan Bacon Conyers, 1988), p. 4-7
} 


\section{Policy Implementation in Improving Teachers' Competence at The Ministry Of Religion Affairs Of North Sumatra Province DOI: 10.30575/2017/IJLRES-2018091210}

at this time was the radicalism movement which had penetrated the world of education as a strong rebuke to the government. Islamic religious education should produce a generation of people with character who will be taught by Islamic religious education (PAI) teachers in schools. On the other hand the teacher is a very dominant and most important factor in education to achieve learning goals in school. The higher the teacher's ability in teaching, it is assumed that the higher learning outcomes that will be achieved by students. The teacher's ability to teach as an educational goal is an indicator of the success of the student's learning process. Therefore, in order to carry out their duties properly in accordance with their profession, the teacher needs to master various things as competencies that must be possessed. Awareness that education must always be responsive to progress has prompted experts and decision makers in the field of education to make updates. In every renewal in the world of education, the teacher always plays an important and strategic role because a teacher is an executor of renewal at the class level. To achieve quality education, one of the things that must be prioritized is efforts to improve the ability of teachers, where teachers are one of the inputs which is a pre-condition for the continuity of the education process. In order to realize character education and improve teacher capacity, the Ministry of Religion c / q in the field of Islamic religious and religious education organizes "increasing the competence of PAI teachers in schools in North Sumatra in 2018". 6

Likewise stated by the Head of Regional Office of the Ministry of Religion in talking about increasing the competence of PAI teachers that:

"The issue of education, first, is how our government complies with the national education law that in order to increase the teaching profession, of course the government does various kinds; first, improving the teaching profession by increasing training, improving the welfare of teachers might make improvements regarding teacher welfare and also about the curriculum process, so the current government how to improve the quality of education is certainly balanced in order to improve both the sarp The activities carried out in this Regional Office are in accordance with what is done by the government, especially the Ministry of Religion in the context of the teacher's professional development program. ${ }^{7}$

In improving competency for PAI teachers, it can be seen from the documents obtained by several activities that improve teacher performance capabilities, which refers to teacher competencies, namely pedagogical competencies, namely in the workshop activities to improve the ability of PAI teacher learning methods in their daily lives, then

${ }^{6}$ Burhanuddin, Head of Religious Education and Islamic Religious Affairs, North Sumatra Provincial Ministry of Religion, Interview in Medan, February 22, 2018

${ }^{7}$ T. Darmansyah, Plt. Head of North Sumatra MoRA Regional Office, Interview in Medan, April $5,2018$. 


\section{Nurhaizan}

social competence, and personality competencies and professional competence for teachers.

As for increasing the competence of PAI teachers, in addition to seminars and various workshops conducted in the Regional Office of the Ministry of Religion, North Sumatra, activities to increase teacher competency are also carried out by the religious training center, which is still under the auspices of the Ministry of Religion, as well as interviews Head of Medan Religious Training Center, who said:

"We are only educational problems, how can teachers be competent in teaching religious education to children, so we are trained here, how to convey, how to provide information to children for better. especially now that people say the term now, we can no longer say and use theory, but we have to practice, even if he already had Islamic law from the beginning it must also be explained in detail so that the education is here even though not all but later can provide information other, then now we use the method of education by means of IT $^{8}$

This was confirmed again by the results of the interview stating that the Regional Office of the Ministry of Religion was only coaching, while the activities to increase the competence of PAI teachers in the form of education and training were organized by the Religious Education and Training, as the questions were asked about the role of the Education and Training Center he asserted that "we are only coaching, if the name of the training goes back to the training center. ${ }^{9}$

Furthermore, it was explained that in coaching with the number of study hours of less than 30 hours, while the head of education and training assemble explained that more than 30 hours of lessons was given, this was revealed based on the results of interviews:

"The purpose of their activities, and there are those who understand and understand them, and we cannot equalize the level of knowledge and understanding of that person, and we try because we are coaching, and we cannot be like this because the types of activities are not large, except in education and training, if the training is different, the training is a lot of hours, so it can be used for days and more swoop, if this is so many resource persons, participants, workshops, and indeed our authority, the ministry cannot carry out many the day and the hour, if it's more than 30 hours, it's already the authority of the training, not us anymore". ${ }^{10}$

\footnotetext{
${ }^{8}$ Khoirul Amani, Head of Medan Religious Training Center, Interview in Medan April 2, 2018.

${ }^{9}$ T. Darmansyah, Plt. Head of North Sumatra Ministry of Religion, Interview in Medan, April 5, 2018.

${ }^{10}$ Wan Khairunnisa, Head of Secondary Education PAI Section, Interview in Medan, April 5, 2018.
} 


\section{Policy Implementation in Improving Teachers' Competence at The Ministry Of Religion Affairs Of North Sumatra Province DOI: 10.30575/2017/IJLRES-2018091210}

Based on the results of the interview, it can be understood that the activities carried out by the North Sumatra Provincial Office of the Ministry of Religion have a slightly different task force and study, different here the workshop activities are only coaching with a predetermined number of study hours, which is only about 2 nights , and those that are out of coaching already exist in the realm of training centers, which are around 30 hours, with concepts that are more focused and concentrated.

Furthermore, it was revealed that the improvement of teacher competence refers to the foundation in its implementation, as revealed that:

"The competence / performance of PAI teachers in the Ministry of Religion of North Sumatra Province can be seen by increasing the ability of PAI teachers about character education, providing motivation in instilling the values of religious education to strengthen Islamic relationship, understanding teacher competencies well, understanding Islamic learning models able to explain the model of scientific teaching and be able to understand pedagogical teaching in fostering brotherhood and national unity among PAI teachers. The basis and foundation of the implementation of the policy of increasing the competence of PAI teachers in the Ministry of Religion of North Sumatra Province is that increasing the competence of teachers, including PAI teachers in schools is a necessity. this is in accordance with the mandate of Law Number 20 of 2003 concerning the National Education System, stated that the goal of national education is the development of potential students to become human believers and fearful to the Almighty God, noble, healthy, knowledgeable, capable, creative , independent and become a democratic and responsible citizen. Furthermore, in the regulation of the Minister of Religion of Republic of Indonesia number 16 of 2010 in Article 13 it is said that religious education teachers must have at least an I / IV strata academy qualification, from religious education study programs and / or religious education study programs. Furthermore, it is stated that PAI teachers in schools must have pedagogical, personality, social, professional and leadership competencies. Thus PAI teachers in schools must have academic qualifications, professional certification and competence". ${ }^{11}$

Based on this reference foundation, there is the role of the Regional Office of the Ministry of Religion in realizing increased competence of PAI teachers, as explained in the following interview

"The role of the Regional Office of the Ministry of Religion in North Sumatra in following up on the policy of increasing CAI teacher cometrics is to prioritize PAI teacher competency programs on DIPA and to socialize to districts / cities to improve PAI teacher competence "12

\footnotetext{
${ }^{11}$ Burhanuddin, Head of Religion and Islamic Religious Education, Interview in Medan, February 22, 2018.

${ }^{12}$ Ibid
} 


\section{Nurhaizan}

Further explained that increasing competence is very important for teachers, especially PAI teachers.

"Increasing the competence of PAI teachers is very important because along with the dynamics of the Directorate General of Islamic Education Through the Directorate of Islamic Education has established a comprehensive policy to support the development of Islamic Education and learning processes in each education unit to strengthen the implementation of the 2013 curriculum and increase teacher competency specifically related to the competence of educators." 13

From many of programs implemented, with the aim that the program of increasing the competence of PAI teachers within the North Sumatra Regional Office of the Ministry of Religion can be described as a concept map as follows:

Concept Map of the Implementation Program for PAI Teacher Competency Improvement Policy in the Ministry of Religion of North Sumatra Province

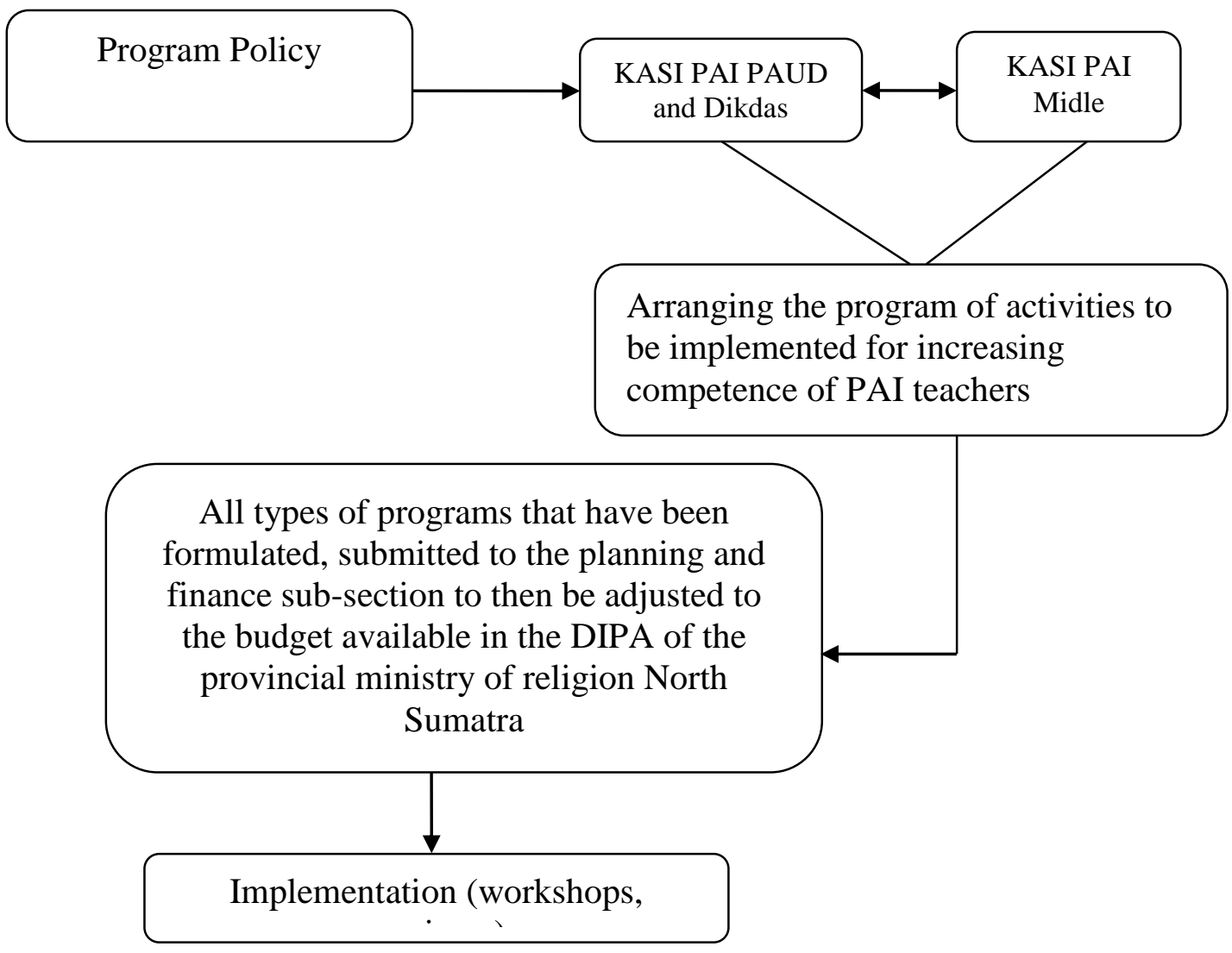




\section{Policy Implementation in Improving Teachers' Competence at The Ministry Of \\ Religion Affairs Of North Sumatra Province \\ DOI: 10.30575/2017/IJLRES-2018091210}

\section{Procedure for Implementing PAI Teacher Competency Improvement Policies in the Ministry of Religion of North Sumatra Province}

Good activities are activities that have been programmed or planned well, then carried out with well-directed and coordinated procedures. The following is an interview with the Head of the Religion and Islamic Religious Education Division (PAKIS).

"The procedure for implementing the competency enhancement activities of PAI teachers in the North Sumatra Regional Office of the Ministry of Religion is that the section conducts the meeting first and then forms a committee, then the committee holds a meeting to determine the implementation time, then after the place and time are set, an invitation letter is sent. participants to the district / city section to present participants who will take part in the activity, participants including PAI elementary, junior high, high school / vocational teachers and even PAI supervisors ". ${ }^{14}$

In the activities carried out, related to the procedures implemented, the head of the middle level section stated that:

"The procedure is long, starting from the proposal being made, if the form is like this, I cannot answer it, it is all a policy, the policy is from the center, from above, I am a technical implementer, it cannot be like this, only we from below suggest first planning system, there will be proposed programs that are in accordance with the development and referring to programs that from the center we have to synchronize the central and regional programs, so all the programs are policies that are all in echelon 1, so I am not a policy maker, I just technical implementers, so the policy is in the Regional Office in echelon 1 if it is at the center, so if the story is policy I cannot answer." 15

After the procedure is implemented according to provisions, in this case various activities are carried out to improve the quality of PAI teachers, as in the following interview, that:

"The activities carried out by the Regional Office of the Ministry of Religion of North Sumatra in the PAI teacher competency improvement program include: workshops to improve PAI teacher competencies, workshops on 2013 curriculum implementation, PAI USBN preparation workshops, workshops on developing learning strategies, PAI teacher appreciation workshops and others". ${ }^{16}$

These activities are carried out in the planned place, where the place aims to provide convenience for the participants and the organizing committee, that:

\footnotetext{
${ }^{14} \mathrm{Ibid}$

${ }^{15}$ Wan Khairunnisa, Head of PAI Section for Secondary Education, Interview in Medan, April 5, 2018.

${ }^{16}$ Burhanuddin, Head of the Religion and Islamic Religious Education Division of North Sumatra Province Ministry of Religion, Interview in Medan, February 22, 2018
} 


\section{Nurhaizan}

"The implementation of competency enhancement activities for PAI teachers in the North Sumatra Ministry of Religion office was held in hotels for 3 days and 2 nights in accordance with the DIPA with the implementation technique guided by resource persons who had TOT certificates as a requirement for tutors in these activities. $^{17}$

The activities carried out at the place are in accordance with the reasons and conditions that have been determined, because in principle the activity is to present and invite participants, this is in accordance with the statement from the following interview

"There is a training program in the hotel because there is a full board activity that is given by the people who present and organize, so the provisions of the types of participants who want to be provided with guidance, if it is in accordance with the budget, the hotel is full board". ${ }^{18}$

Based on the interview above, it can be seen that the activities held by the Regional Office of the Ministry of Religion are divided into two sessions, namely at the DIKDAS and Intermediate level with established procedures and well-coordinated.

Talking about activities, this is inseparable from a number of things that are interrelated with participation so that the implementation of this activity, that:

"Who participated in the implementation of activities to increase the competence of PAI teachers in the Regional Office of the Ministry of Religion of North Sumatra province, some PAI teachers who had become national instructors who had training of trainers, KABID, Regional Offices and officials in Regional Offices and PAI teachers who had been sent going abroad such as Oxfort University London and Australia in GPAI methodology learning deliveries that have been sent by the PAI directorate, then those who participate later are educational institutions in schools such as FKG, KKG, MGMP and PAI Pokjawas". ${ }^{19}$

In addition, in participating to this activity, the participants who were participants and who were involved in various activities to improve the competence of PAI teachers, according to the interview with the Head of Training Center, namely:

"All involved in this activity include those in Regional Offices, PAIS, Pakis, Pusdiklat and all involved in the implementation of this activity, the material taught and have a curriculum issued by the education center that has been signed by the head of the Direct Research and Development Agency applied and used.

\footnotetext{
${ }^{17}$ ibid

${ }^{18}$ Wan Khairunnisah, Head of PAI Section for Secondary Education, Interview in Medan, April 5,2018

${ }^{19}$ Burhanuddin, Head of North Sumatra Religion and Islamic Religious Education Division, Interview in Medan, February 22, 2018

${ }^{20}$ Khairul Amani, Head of the Medan Religious Training Center, Interview in the Workspace Tanggl April 2, 2018 At 8:00 a.m.
} 


\section{Policy Implementation in Improving Teachers' Competence at The Ministry Of \\ Religion Affairs Of North Sumatra Province \\ DOI: 10.30575/2017/IJLRES-2018091210}

Participant who involved in this activity are part of the field that does have the ability and good potential in handling this activity, it has indeed been determined, in accordance with the human resources that have been placed with the job description signed by the head of the Division to be carried out as well as possible.

\section{CONCLUSION}

Based on the results of the above research, things can be concluded as follows:

1. Regional Office of the Ministry of Religion of North Sumatra Province has implemented various programs to improve teacher competence through workshops, training, seminars and mentoring.

2. Head of Islamic Religious Education (PAKIS) as part of specifically dealing with the field of Islamic religious teacher education, has implemented the program integrally in terms of fostering PAI teachers in Junior High Schools and Upper Middle School throughout the North Sumatra Province. The programs are oriented towards increasing the competence of PAI teachers to become reliable and competent teachers according to their expertise.

3. In general, the Office of the Ministry of Religion of North Sumatra province has budgeted funds to increase teacher competency. The budget is regulated in the DIPA in detail.

4. In each teacher enhancement activity, the participants are always active and responsive participants, so it is believed that after they return to their respective Schools, they will be able to apply what they have obtained in the training.

\section{BIBILIOGRAPHY}

Abidin, Said Zainal, Kebijakan Publik (Jakarta: Suara Bebas, 2006),Al-Kanani, Badruddin Ibnu Jama'ah, Tazkirah Al-Sam'i Wa Al Mutakallim Fi Adab Al Alim Wa Al Mutaallim (Beirut:Dar Al Kutub, 1978)

Anderson, James E. Dan David W. Bradi Et.Al, Public Policy And Polities In Amerika, Monterey, CA: Brooks/Cole Publishing Company, 1984.

Al-Rasyidin, Falsafah Pendidikan Islam, Bandung:Citapustaka, 2015.

Kepribadian Dan Pendidikan, Bandung;Cita Pustaka Media, 2006. 


\section{Nurhaizan}

Abd Al-Salam, Abd Al-Wahab, Al-Tarbiyah Al-Islamiyahwa Fan Al-Tadris, Mishr Darul Salam, 1418.

Azmi, Fachruddin, Kebijakan Pendidikan Islam, Memberdayakan Peradaban, Medan, Manhaj, 2016.

Daulay, Haidar Putra, Pendidikan Islam Dalam Sistem Pendidikan Nasional (Jakarta:Kencana Prenada Media, 2012, Edisi Revisi.

Rineka Cipta, 2012.

Dunn, William N., Public Policy Analysis:An Introduction, Englewood, Cliffs, N.J. : Prentice- Hall, Inc, 1981.

Depdiknas, Pedoman Sertifikasi Guru Dalam Jabatan (Jakarta:Dikti, 2007).

Duke, Daniel L And Robert Lynn Canady, School Policy (New York:Mcgraw Hill, Inc, 1991

Drummond, H, Pengambilan Keputusan Yang Efektif, Jakarta:Gramedia, 1995.

Dwijowijoto,Riant Nugroho Kebijakan Public: Formulasi, Implementasi Dan Evaluasi, Jakarta:Elek Computindo, 2003.

Echols Dan Shadly, Kamus Inggris Indonesia, Jakarta:Gramedia, 2002.

Fattah, Nanang, Landasan Manejemen Pendidikan, Bandung:Remaja Rosdakarya, 2004.

Grindle, Merilee S, Politics And Policy Implementation In The Third World, New Jersey:Princeton University Press, 1980.

Huda, Nurul, Dkk, Keuangan Publik Islami Pendekatan Teoritis Dan Sejarah, Jakarta:Kencana Prenada Media Group, 2012.

H. M. Hasbullah, Kebijakan Pendidikan Dalam Prespektif Teori, Aplikasi, Dan Kondisi Objektif Pendidikan Di Indonesia, Jakarta:Raja Grafindo, 2016.

Imran, Ali, Kebijaksanaan Pendidikan Di Indonesia:Proses, Produk, Dan Masa Depannya, Jakarta:Bumi Aksara, 2008.

Jauhari, Mohammad, Implementasi PAIKEM Dari Behavioristik Hingga Konstruktivistik, Jakarta:Prestasi Pustaka Publishing, 2011.

Jurnal "Analisa" Volume XVIII No 02, Juli-Desember 2011Mulyani Mudis Taruna, Perbedaan Kompetensi Guru Pendidikan Agama Islam (Studi Kompetensi Guru PAI Tersertifikasi Dan Belum Tersertifikasi Di MTs Kabupaten Banjar Kalimantan Selatan). 


\section{Policy Implementation in Improving Teachers' Competence at The Ministry Of \\ Religion Affairs Of North Sumatra Province \\ DOI: 10.30575/2017/IJLRES-2018091210}

Jurnal Wahana Akademika Vol.2 No. 1, April 2015. Amin Farih, Kesiapan Guru Madrasah Di Kota Semarang Dalam Menghadapi Pelaksanaan PPG (Pendidikan Profesi Guru.

Jurnal Ilmiah Didaktika Bulan Agustus 2015 Pada Vol. 16, No. I, Eka Agusniar, Kemampuan Profesionalisme Guru Bidang Studi Pendidikan Agama Islam Dalam Meningkatkan Prestasi Belajar Siswa SDN 1 Simpang Peut Nagan Raya.

Jurnal Ilmu-Ilmu Keislaman, Vol XL No. 2 Juli-Desember 2016, Miqat, Medan:UINSU Press

Amiruddin Siahaan, Profesionalitas Guru Menurut M. Quraish Shihab Dalam Tafsir Al-Misbah.

Jurnal Pendidikan Dan Ilmu Kependidikan, Vol I No. 1 Januari-April 2016, Lathifah Hanum, Manajemen Pelatihan Pendidik Dan Tenaga Kependidikan Dalam Peningkatan Mutu Pendidikan Di MAN 2 Langsa-Aceh, Cendekia: Medan: Lembaga Peduli Pengembangan Pendidikan Indoesia (LPPPI).

Jurnal Ilmu-Ilmu Keislaman, Vol XL No. 2 Juli-Desember 2016, Zulfikar Ali Buto, Pengembangan Kompetensi Profesionalisme Guru PAI Di Aceh, Miqat, Medan:UINSU Press.

Jurnal Pendidikan Dan Ilmu Kependidikan, Vol I No. 3 September-Desember 2016, Syafira Hasibuan, Peningkatan Kompetensi Guru Bahasa Dan Sastra Indonesia Sebagai Upaya Penguatan Jati Diri Bangsa Di Era Global Village, Cendikia, Medan: Lembaga Peduli Pengembangan Pendidikan Indoesia (LPPPI).

Journal Of Arts Education, Universitas Negeri Semarang,:2014 ISSN 2252-662, Ardian Setiaji "Professionalism Junior School Art Teacher Throughout is Batang, Eduart.

Jurnal Kebijakan Dan Pengembangan Pendidikan, Volume 3, Nomor 1 Januari 2015, ISSN:2337;EISSN:2337-7615, Ninik Sumiarsi, Analisis Kompetensi Pedagogic Dan Pengembangan Pembelajaran Guru SD Negeri 041 Tarakan.

Jurnal Pendidikan Kewarganegaraan, Volume 7, Nomor 2, Nopember 2017, Juliat Widya Dwintari, Kompetensi Kepribadian Guru Dalam Pembelajaran Pendidikan Kewarganegaraan Berbasis Penguatan Pendidikan Karakter,

Jurnal Riset LPPM Universitas Nahdlatul Ulama Blitar, Vol 2 Nomor 4 Tahun 2017 , Anindhita Chumaida:Upaya Sekolah Dalam Meningkatkan Kompetensi Guru PAI Yang Belum Tersertifikasi Di MA Al Hikmah Langkapan Srengat Blitar.

Jones, Charless, An Introduction To The Study Of Public Policy, $2^{\text {nd }}$, Ed, North Scituate, MA. Duxbury Press, 1977

Kompri, Manajemen Pendidikan (Komponen-Komponen Elementer Kemajuan Sekolah) (Yogyakarta: Ar-Ruzz media, 2015). 


\section{Nurhaizan}

Lubis' Lahmuddin-Elfiah Muchtar, Pendidikan Agama Dalam Perspektif Islam, Kristen Dan Budha, Bandung:Cita Pustaka, 2013.

Lubis, Saiful Akhyar, Profesi Keguruan, Bandung:Citapustaka, 2010.

Margono, S. Metodologi Penelitian Pendidikan, cet. 1, Jakarta:Rineka Cipta, 1997.

Muh. Hambali, Manajemen Pengembangan Kompetensi Guru PAI, Jurnal MPI Vol. 1 Tahun 2016

Mulyasa, E, Standar Kompetensi Dan Sertifiksasi Guru (Bandung: Remaja Rosdakarya, 2006)

Musfah, Jejen, Manajemen Pendidikan Dari Teori, Kebijakan Dan Praktik (Jakarta:Kencana Prenada Media Group, 2015).

Nata, Abuddin, Pespektif Islam Tentang Strategi Belajar Mengajar (Jakarta:Kencana Prenada Media Group, 2011)

Owen, Jowen M, program evaluation (forms and Approaces) (Australia:Allen \&Unwin, 2006.

Pongtuluran, Aris, Kebijakan Organisasi Dan Pengambilan Keputusan Manajerial, Jakarta:LPMP, 1995.

Purwanto, Erwan Agus -Dyah Ratih Sulistystuti, Implemenmtasi Kebijakan Public, Yogyakarta,:Gava Media, 2012.

Peraturan Menteri Negara Aparatur Negara Dan Reformasi Birokrasi (Permenneg PAN Dan RB) Nomor 16 Tahun 2009

Qomar, Mujamil, Manajemen Pendidikan Islam, Jakarta:Erlangga, 2010

Ramayulis, Ilmu Pendidikan Islam, Jakarta: Kalam Mulia, 1989.

, Metodologi Pendidikan Agama Islam, Jakarta:Kalam Mulia, 2002.

Ruky A.S., Sistem Manajemen Kerja (Jakarta: Gramedia Pustaka, 2002)

Sagala, Syaiful, Kemampuan Profesional Guru Dan Tenaga Kependidikan (Bandung:Alfabeta, 2009.

Sanjaya, Wina, Strategi Pembelajaran Berorientasi Standar Proses Pendidikan (Jakarta:Kencanaprenada Media Group, 2006.

Semiawan, Conny R., Dimensi Kreatif Dalam Filsafat Ilmu (Bandung:Ramaja Rosdakarya, 1999), 


\section{Policy Implementation in Improving Teachers' Competence at The Ministry Of Religion Affairs Of North Sumatra Province \\ DOI: 10.30575/2017/IJLRES-2018091210}

Stufflebeam, Daniel L, dkk, Evaluation Models (Viewpoints On Educational And Human Services Evaluation, New York: Kluwer Academic Publisher:2002.

Sudian, Anas, Pengantar Evaluasi Pendidikan, Jakarta:Grafindo Persada, 2005.

Suprianto, J., Penilaian Kinerja Dan Pengmbangan Guru (Yogyakarta:BPFE, 1996.

Suyanto-Asep Jihad, Menjadi Guru Profesional, Jakarta:Erlangga, 2013.

Sputt, Allen J And J. Freed Springer, Policy Research New Jersey : Prantice Hall, 1989

Syafaruddin, Efektifitas Kebijakan Pendidikan (Konsep, Strategi, Dan Aplikasi Kebijakan Menuju Organisasi Sekolah Efektif) (Jakarta: Rineka Cipta, 2008)

Syafaruddin-Anzizhan, Sistem Pengambilan Keputusan Pendidikan (Jakarta:Grasindo, 2004)

Syafaruddin-Nurgaya Pasya, Ilmu Pendidikan Islam (Melejitkan Potensi Budaya Ummat) (Jakarta:Hijri Pustaka Utama, 2009

Sugiono, Metodologi Penelitian Pendidikan, Cet. 7, Bandung:Alfabeta, 2009.

Saud, Udin Syaefuddin, Pengembangan Profesi Guru, Bandung:Alfabeta, 2010.

Thaha, M. Chabib, Teknik-Teknik Evaluasi Pendidikan (Jakarta: Raja Grafindo, 1990.

Usman, Nasir, Manajemen Peningkatan Mutu Kinrja Guru (Bandung:Citapustaka Media Perintis, 2012.

Undang-Undang Nomor 14 Tahun 2005 Tentang Guru Dan Dosen 